\title{
Foliar Application of Boron during Flowering Promotes Tolerance to Cocoa (Theobroma cacao L.) Swollen Shoot Viral Disease
}

\author{
Sara Georgina Kouadio, (Agronomist) \\ Houphouet-Boigny National Polytechnic Institute, Higher School of \\ Agronomy, BP 1313 Yamoussoukro, Côte d'Ivoire. \\ Eric-Olivier Tienebo, (Assistant, MSc, Plant Pathologist) \\ Kouakou Théodore Kouadio, (Assistant Professor, Ph.D., Plant \\ Virologist)
}

Koffi Badou Jérémie Kouamé, (Assistant, MSc, Weeds Scientist)

Houphouet-Boigny National Polytechnic Institute, Department of Agriculture and Animal Resources, Laboratory of Plant Pathology and Biology, BP 1313 Yamoussoukro, Côte-d'Ivoire

Louis Koko, (Research Scientist, Ph.D. Pedologist)

Center for Agronomic Research, CNRA-Divo/Programme cacao. BP 808 Divo/Côte d'Ivoire.

Kouabenan Abo, (Associate Professor, Ph.D., Plant Pathologist)

Houphouet-Boigny National Polytechnic Institute, Department of Agriculture and Animal Resources, Laboratory of Plant Pathology and Biology, BP 1313 Yamoussoukro, Côte-d'Ivoire

doi: 10.19044/esj.2017.v13n21p387 URL:http://dx.doi.org/10.19044/esj.2017.v13n21p387

\begin{abstract}
Boron nutrition is known to reduce the effect of some viral and fungal diseases on plant fitness. This study investigated the potential of boron application to improve yield and tolerance of cacao trees naturally infected by virulent cocoa swollen shoot virus (CSSV) strains and determined the effective dose and time of application. Foliar sprays of a commercial product containing $20.5 \%$ of boron were performed either at the onset of flowering's peak of the little milking (early in November) or four weeks later (early in December) with four doses of boron $(0,31.25,41.67$, and $83.27 \mathrm{~g} / \mathrm{ha}$ ) in a randomized complete block design with four replications. We found that boron application improved foliar density and induced production of pods of normal shape meanwhile reducing the appearance of this misshapenness due to CSSV. Boron also increased the number of emitted flowers, cherelles and pods subsequently. Moreover,
\end{abstract}


weight and size of fresh cocoa beans per pod were positively correlated to boron dosage. Interestingly, foliar sprays performed early in November resulted in less flat cocoa beans. Finally, the optimal dose of boron that reduced the adverse effects of the most virulent form of cocoa swollen shoot viral disease is $41.67 \mathrm{~g} / \mathrm{ha}$.

Keywords: Boron, Swollen shoot virus, cocoa, Tolerance

\section{Introduction}

Cocoa Swollen Shoot Virus Disease (CSSVD) remains a serious threat to chocolate industry and the economy of the producers of cocoa beans (Ploetz, 2007; Dzahini-Obiatey et al., 2010; Kouakou et al., 2011; Ameyaw et al., 2013, 2014) since its first reporting in Ghana in 1936 (Kouakou et al., $2011 \&$ 2012). The CSSVD is also widespread to other West African countries including Nigeria, Côte d'Ivoire, Sierra Leone, and Togo. (Lockhart et Sackey, 2001; Vos et al., 2003; Kouakou et al., 2011 Ameyaw et al., 2014; Patriot, 1983). The disease causes the characteristic symptoms of ribs' reddening and foliar mosaic but mainly the swelling of shoots and roots (Kouakou et al., 2011). Although the most severe form of CSSVD can kill cacao trees in less than three years (Partiot et al., 1978), attenuated forms have also been reported (Ollennu et Owusu, 2002; Ameyaw et al., 2016). There are more than forty Malvaceae plants as well as other plant species enfeoffed to West African ecosystems, such as Cola chlamydantha K. Schum, Adansonia digitata L. and Ceiba pentandra (L) Gaerth that naturally host the viruses (Ploezt, 2007). The Cocoa Swollen Shoot Virus (CSSV), the causal agent, belongs to the Badnavirus genus of the Caulimoviridae family (Lockhart, 1990; Bhat et al., 2016). The CSSV is vectored semi-persistently by more than 14 Pseudoccidae mealybugs species. However, Planococcoides njalensis and Planococcus citri are the major vectors (Dongo et Orisajo, 2007; Ploezt, 2007).

Since the resurgence of the CSSVD in 2003 in the Ivorian orchard (Kébé et al., 2009) after 60 years, insecticidal applications to control the vectors did not hinder the endemic. The main control performed by the growers is the uprooting of the infected trees, but this sanitation does not control the pathogen vector. Genetic approaches are promising, but no resistant clone is commercially available to date. Alternative methods need to be assessed. Even though genetic resistance/tolerance is inherent to the plant genotype, it is strongly influenced by environmental factors (Spann et Schumann, 2010). Since mineral nutrition is one of the controllable elements of the environment, it can, therefore, increase plant resistance or tolerance to pathogens and insects (Gao et al., 2014; Eraslan,2007; Altieri and Nicholls, 2003; Kraussa et al., 2001). 
The oligo-element boron is well-known to reinforce plant resistance to certain parasitic diseases while ensuring a good yield (Kraussa et al., 2001). According to research in Nigeria, boron has reduced the effects of Theobroma cacao pod brown rot by increasing the percentage of healthy pods (Olaiya et al., 2006). It has also been reported that boron reduced the effects of viruses such as Tobacco mosaic virus (TMV) on beans and Tomato yellow leaf curl virus (TYLCV) on tomatoes (Dordas, 2008). The use of mineral fertilization, particularly boron, in Ivorian cacaoculture is not new. Some firms offer formulas incorporating boron (Koko et al., 2011).

This study, therefore, was carried out in a naturally infected field by putatively the most virulent CSSV strains (Groups B, C, or B-C) to investigate the effects of a commercial fertilizer (containing $20.5 \%$ of boron) from Louis Dreyfus Commodities (LDC) company on both yield of CSSVdiseased cacao trees and disease development. The effective dose and period of application to obtain a significant increase in yield and a better quality of the cocoa beans were determined. Boron was applied by foliar spraying. The trial was carried out in Bouaflé, a zone of high prevalence of the disease in central Côte d'Ivoire.

\section{Materials and Methods}

\section{Pedoclimatic characteristics of the study area}

This study was carried out, in at Garango $\left(07^{\circ} 01^{\prime} \mathrm{N}, 05^{\circ} 47^{\prime} \mathrm{W}\right)$, a village in the Department of Bouaflé (Central west Cote d'Ivoire). The experimental field was located about $3 \mathrm{~km}$ northwest of the village (Koko et al. 2013). The study area undergoes a humid equatorial climate characterized by two rainy seasons and two dry seasons (Ouattara, 2008). During the year prior our trial, the rainfall ranged from $16 \mathrm{~mm}$ (in December) to $276 \mathrm{~mm}$ (in June), with a monthly average of $112.08 \mathrm{~mm}$. During the experiment, the rainfall was between $0 \mathrm{~mm}$ in January, and $102 \mathrm{~mm}$ in February, and the average temperature was $30 \pm 5^{\circ} \mathrm{C}$. The soil type was a loamy soil with a

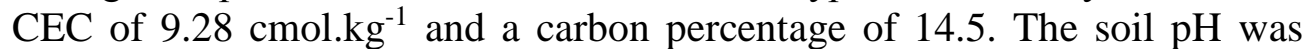
7.29. The CEC was low according to the interpretation of Calvet et al. (1986), and the K-Ca-Mg equilibrium is $8.8 \%-78.6 \%-10.9 \%$ of the sum of the exchangeable bases.

\section{Plant material}

Cultivated cacao-trees were a consortium of 16-years-old hybrids (H109, H125, H117, H140, H153) with similar agronomic potential (yield, cocoa beans' weight, susceptibility to CSSVD), and derived from thirdgeneration crosses performed and commercialized by the Ivorian national center of agronomic research (CNRA). The plantation was naturally infected by the CSSV. 


\section{Period and dose of foliar application of boron}

A factorial experimental design with two factors, period and dose of application, was used. The period of application has two levels (early application in November and late application in December). These two selected periods correspond to a maximum of flowering. Indeed, the flowering's peak for the little milking runs from November to January. Therefore, the early application occurred at the onset of this peak and the late application occurred four weeks later. These periods of application intervene during flowering because boron is well assimilated by the plant at this phenological stage (FAO, 2003).

The application dose had four levels: a control (only water sprayed on leaves), $31.25,41.67$, and $83.27 \mathrm{~g} /$ ha of boron, respectively equivalent to $0,152.46,203.28$, and $406.18 \mathrm{~g} / \mathrm{ha}$ of a commercial product. $41.67 \mathrm{~g} / \mathrm{ha}$ is the recommended dose by the seller (LDC company) for the routine cultural itinerary. Application of the product was performed on the leaves foliar with an atomizer. The trial lasted four months from November to February.

\section{Experimental Design}

The experimental design was a randomized complete block design with two factors and four replications. The block design was intented to block the effect of variation in field' solar lighting which follows the field slope. The combination of the levels of these factors gives eight treatments. Experimental unit consisted of 24 trees covering $180 \mathrm{~m}^{2}(12 \mathrm{~m} \times 15 \mathrm{~m})$. Two lines of cacao trees were left out to mark the demarcation between blocks and between plots. To avoid border effects, observations were performed in the central part of the experimental unit on four trees showing symptoms of the disease. The useful area was 9,317 $\mathrm{m}^{2}$. Weeds and insects were controlled, one-month prior applications of boron in November, by Glyphosate and Acetamiprid + Cypermethrin, respectively. Pod brown rot was not observed on plots during the experiment.

\section{Response variables}

The below-mentioned response variables were measured on or from the same trees.

1. The flowering intensity is defined by the number of flowers that fall per square meter over a period of observation. It was determined every 15 days on $1 \mathrm{~m}^{2}$ plastic nets placed randomly inside the plot (Lachenaud, 1985). The intensity of flowering was calculated per month;

2. The number of cherelles per tree: The cherelles were counted every 15 days. The cherelles formed well before the test was set up were marked and not counted;

3. The number of pods per tree was counted on the main trunk; 
4. Technological parameters: These are the fresh weight of full pods, fresh weight of cocoa beans per pod, and number of flat cocoa beans, as well as length and width of cocoa beans. Kouakou et al. (2011) showed that the CSSVD decreased the quality of these parameters. Once the pods were ripe, a sample of five pods was collected from each experimental unit. Weights were obtained with a $10^{-1}$ micro precision electronic balance;

5. Typical symptoms of CSSVD: Interveinal chlorosis, reddening of young leaves, mosaic on adult leaves, swollen shoots and defoliation of trees were monitored.

The above parameters were relevant as indicators of productivity or/and of CSSVD presence and severity (Mossu et al., 1981; Kouakou et al., 2011).

\section{Statistical analysis}

The flowering intensities data per treatment were used to calculate the coefficients of evolution of the flowering intensities. These coefficients $\left(\mathbf{T}_{\mathbf{i})}\right.$ were determined from formula 1:

$$
\boldsymbol{T}_{\boldsymbol{i}}=\left(\frac{\boldsymbol{n}_{\boldsymbol{i}}}{\boldsymbol{n}_{2}}\right) . \quad[1]
$$

Where $\mathbf{n}_{\mathbf{i}}$ is the value of flowering intensity for the $\mathrm{i}^{\text {th }}$ week since the beginning of November. The XLSTAT 2017 software package (Paris, France) was used to compute ANOVA at the significance level of 5\% on the means of the parameters: coefficient of evolution of the flowering intensities, number of cherelles, number of pods, fresh weight of pods, total fresh weight of cocoa beans and length and width of cocoa beans. These parameter's means were box-cox transformed when the assumptions of ANOVA were not satisfied. Duncan test was used for multiple pairwise comparisons after rejecting the null hypothesis in ANOVA. A principal component analysis was also computed to display the significant correlations between all measured response variables.

\section{Results}

\section{Presence of typical CSSVD symptoms before experimentation}

Table 1 summarizes the nature of the disease symptoms observed before the experimentation begins and the illustrations of the symptoms are in Figures 1 - 4.

Table 1: Nature of the symptoms observed on plot

\begin{tabular}{|c|c|c|c|c|c|c|c|}
\hline \multicolumn{1}{|c|}{ Leaves } & $\begin{array}{c}\text { Pod } \\
\mathrm{s}\end{array}$ & $\begin{array}{c}\text { Twi } \\
\text { gs }\end{array}$ \\
\hline $\begin{array}{c}\text { Redd } \\
\text { ening }\end{array}$ & $\begin{array}{c}\text { Fe } \\
\text { rn-like } \\
\text { Mosaic }\end{array}$ & $\begin{array}{c}\text { Reticul } \\
\text { ated } \\
\text { mosaics }\end{array}$ & $\begin{array}{c}\text { Chlo } \\
\text { rosis of } \\
\text { the leaf }\end{array}$ & $\begin{array}{c}\text { Vei } \\
\text { clearing }\end{array}$ & $\begin{array}{c}\text { fili } \\
\text { form } \\
\text { leaf }\end{array}$ & $\begin{array}{c}\text { Sm } \\
\text { all and } \\
\text { rounded }\end{array}$ & $\begin{array}{c}\text { Swe } \\
\text { lling of } \\
\text { branches }\end{array}$ \\
\hline
\end{tabular}




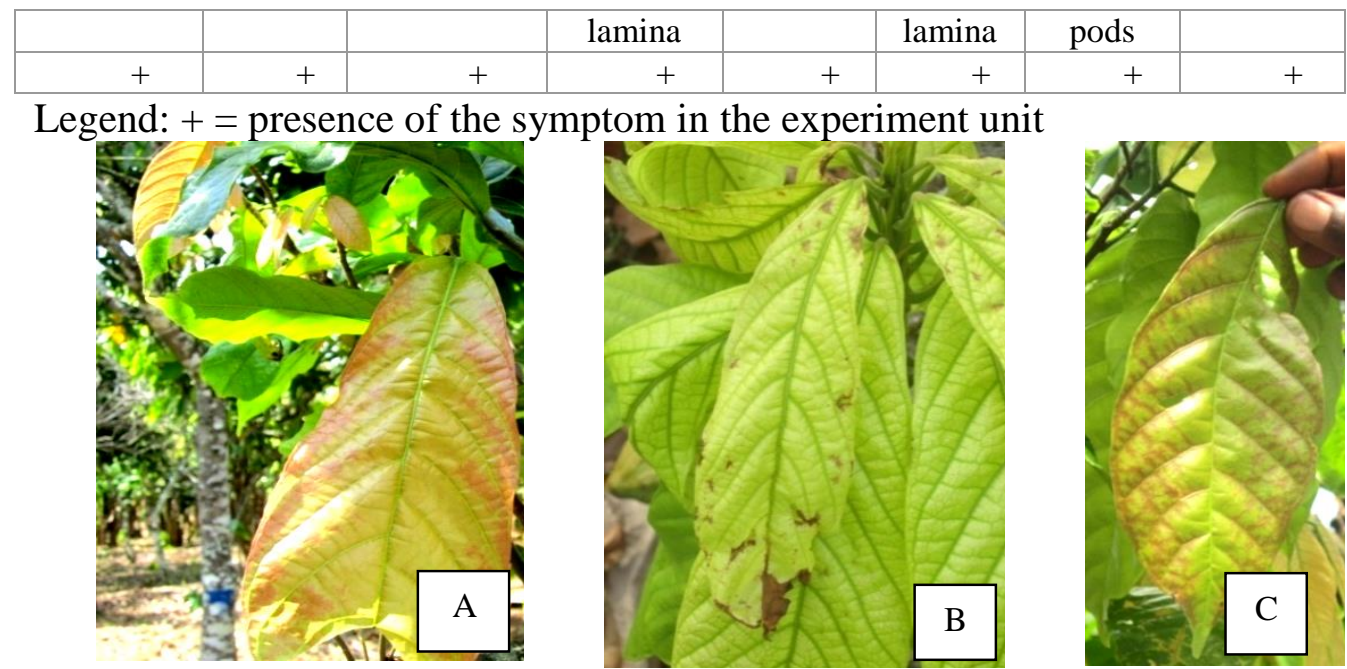

Figure 1: Symptoms of swollen shoot disease on leaf

A: Red bands on young leaves; B: Chlorosis and filiform leaf lamina; C: Reddening of the ribs

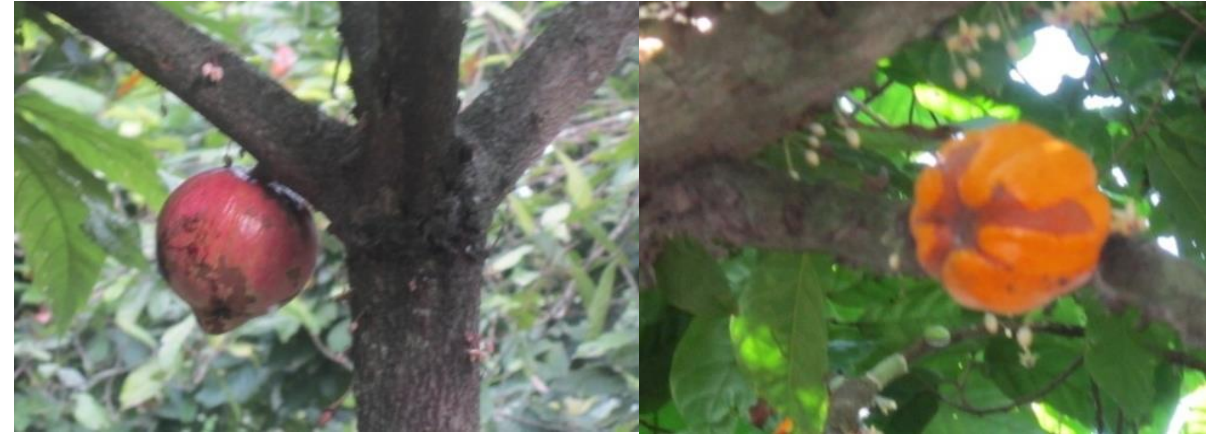

Figure 2: Rounded cocoa pods

Although twigs swellings were not clearly marked, a slight swelling of branches (Figure 3) and a heavy defoliation of some trees were visible (Figure 4).

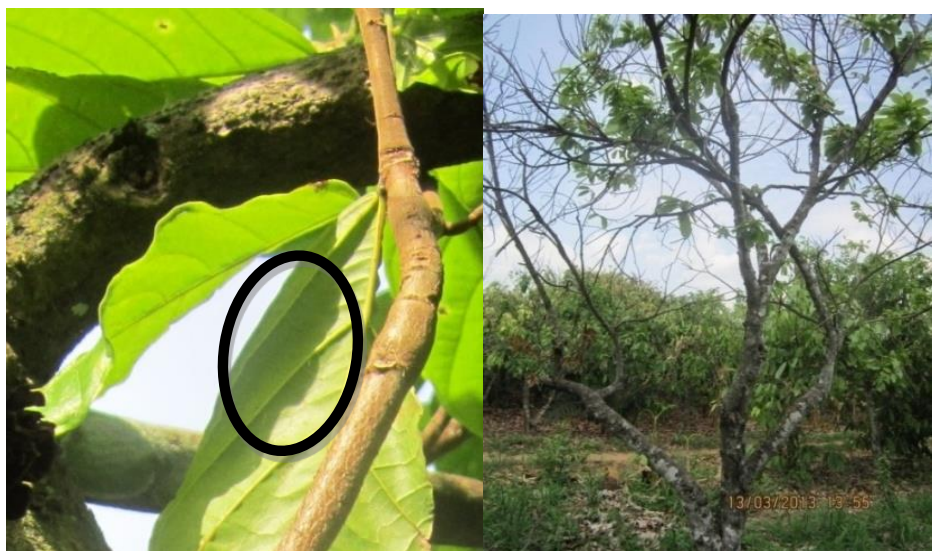

Figure 3: Twig' swelling due to CSSV. Figure 4: Defoliated tree in an experimental unit 


\section{Boron increases leaf density and normally shaped pods on CSSVD- stressed trees}

Boron spraying with $41.67 \mathrm{~g} / \mathrm{ha}$ and $83.27 \mathrm{~g} / \mathrm{ha}$ increased the density of the foliage (Figure 5 and 6). This increase was observed eight weeks after application at the onset of the flowering peak.

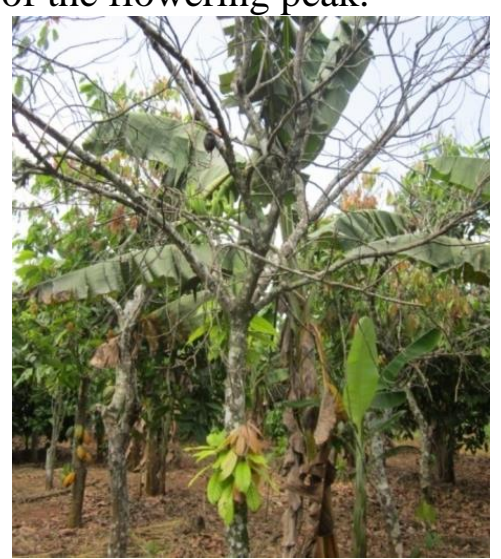

Figure 5: Defoliation observed before treatment (photo taken early in November)

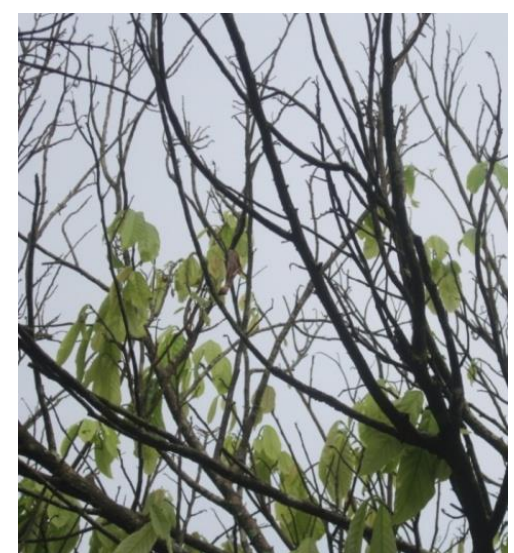

Figure 6: Thrust of newly-formed leaves on treated tree pictured in Figure 5 (photo taken in January)

However, trees that have received $31.25 \mathrm{~g} / \mathrm{ha}$ or $41.67 \mathrm{~g} / \mathrm{ha}$ of boron exhibited significantly more deformed pods (Figure 7,11$)$ than trees treated with $83.27 \mathrm{~g} / \mathrm{ha}$ (Figure 8,11) but less than the control (Figure 11). 


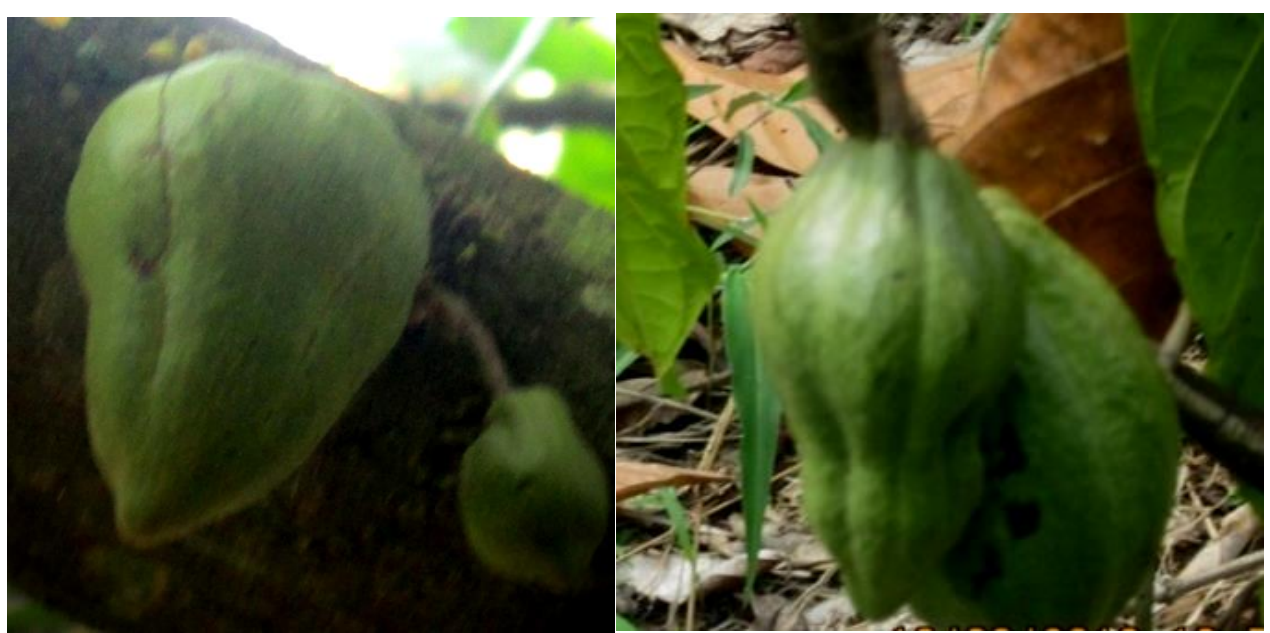

Figure 7: Deformed pods on a cacao tree treated with 31.25 or $41.67 \mathrm{~g} / \mathrm{ha}$ of boron

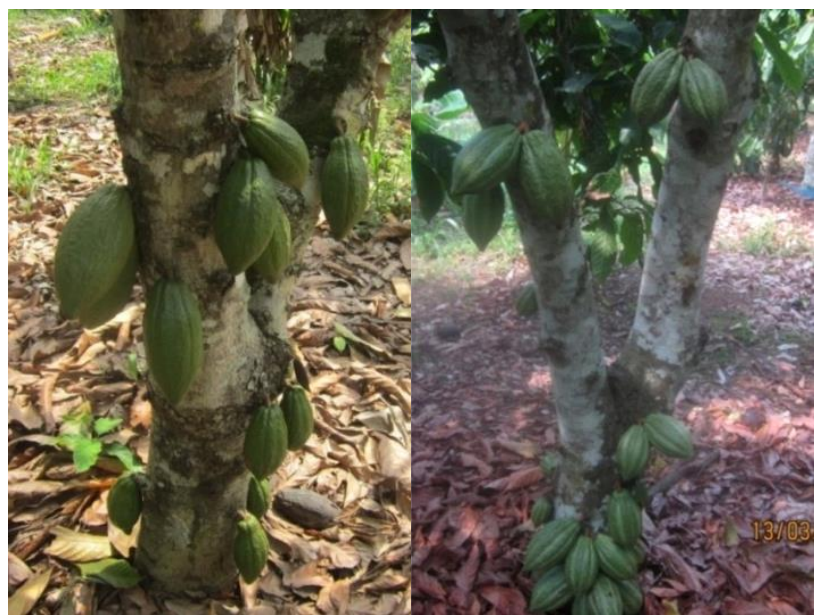

Figure 8: Normally shaped pods on a cacao tree treated with $83.27 \mathrm{~g} / \mathrm{ha}$ of boron

\section{Boron improves floral emission differently depending on the period of application}

The number of fallen flowers per month and per square meter allowed to calculate the coefficients of evolution of the flowering intensities every two weeks post boron's application. The dose of $83.27 \mathrm{~g} / \mathrm{ha}$ conferred the strongest positive effect on the flowering during two months (Figure 9, Table 2) where the intensity of flowering was at least 3- to 9-fold its value at two weeks post flowering peak onset. 


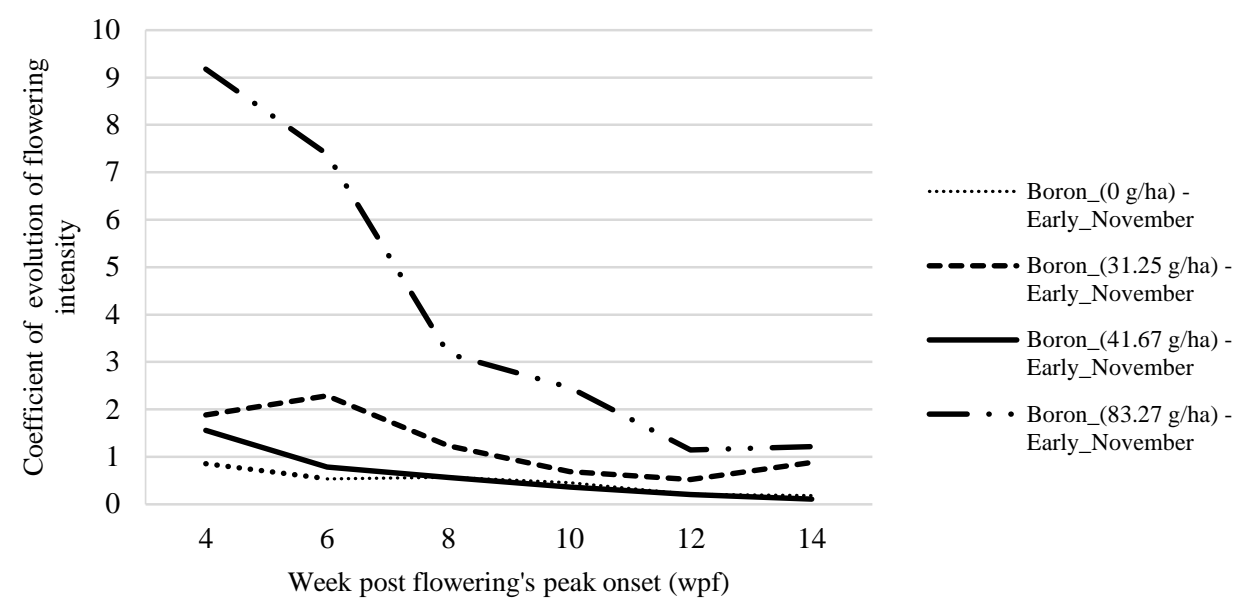

Figure 9: Evolution of flowering intensities of trees treated early in November.

The values are means of 4 replicates. wpf: Week post flowering's peak onset.

Table 2: Coefficients of evolution of flowering intensities for application early in November

\begin{tabular}{ccccccc}
\hline Doses & $4 \mathrm{wpf}$ & $6 \mathrm{wpf}$ & $8 \mathrm{wpf}$ & $10 \mathrm{wpf}$ & $12 \mathrm{wpf}$ & $14 \mathrm{wpf}$ \\
\hline Boron_(0 g/ha) & $0.856 \pm$ & $0.536 \pm$ & $0.571 \pm$ & $0.458 \pm$ & $0.214 \pm$ & $1.143 \pm$ \\
Boron_(31.25 & $0.028 \mathrm{a}$ & $0.060 \mathrm{a}$ & $0.236 \mathrm{a}$ & $0.129 \mathrm{a}$ & $0.110 \mathrm{a}$ & $0.050 \mathrm{a}$ \\
g/ha) & $0.176 \mathrm{~b}$ & $0.855 \mathrm{~b}$ & $0.191 \mathrm{ab}$ & $0.027 \mathrm{a}$ & $0.019 \mathrm{a}$ & $0.090 \mathrm{a}$ \\
Boron_(41.67 & $1.560 \pm$ & $0.787 \pm$ & $0.565 \pm$ & $0.360 \pm$ & $0.203 \pm$ & $0.823 \pm$ \\
g/ha) & $0.400 \mathrm{~b}$ & $0.007 \mathrm{a}$ & $0.107 \mathrm{a}$ & $0.023 \mathrm{a}$ & $0.094 \mathrm{a}$ & $0.043 \mathrm{a}$ \\
Boron_(83.27 & $9.176 \pm$ & $7.388 \pm$ & $3.178 \pm$ & $2.467 \pm$ & $1.146 \pm$ & $0.543 \pm$ \\
g/ha) & $3.880 \mathrm{c}$ & $0.757 \mathrm{c}$ & $0.634 \mathrm{~b}$ & $1.879 \mathrm{a}$ & $0.568 \mathrm{a}$ & $1.045 \mathrm{a}$ \\
\hline Pr $>$ F & 0.008 & 0.003 & 0.041 & 0.178 & 0.155 & 0.883 \\
Significant effect & Yes & Yes & Yes & No & No & No \\
\hline
\end{tabular}

The means of 4 replicates \pm SE followed by the same letter are not significantly different. Data were box-cox transformed before computing ANOVA. wpf: Week post flowering's peak onset.

Boron applied early in December did not improve the coefficient of evolution of the flowering intensities significantly compared to the control (all p-values >0.05) (data not shown).

\section{Boron induces a higher number of cherelles on cacao trees affected by swollen shoot disease}

Globally, higher doses of boron applied early in the peak of flowering promoted a number of cherelles significantly greater of that of the control 
(Figure 10, Table 3), the month following the application. However, the effect did not last one another month.

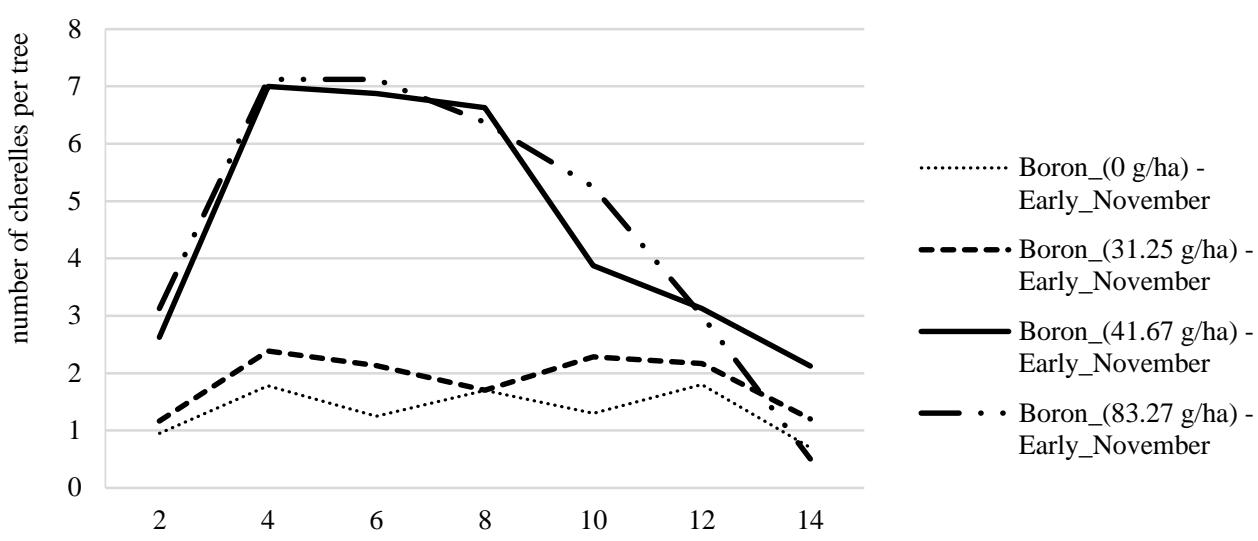

Week post flowering's peak onset (wpf)

Figure 10: Evolution of the number of cherelles on trees treated early in November

The values are means of 4 replicates. Wpf: Week post flowering's peak onset.

Table 3: Number of cherelles recorded every two weeks after application early in November

\begin{tabular}{|c|c|c|c|c|c|c|c|}
\hline Doses & $2 \mathrm{wpf}$ & $4 \mathrm{wpf}$ & $6 \mathrm{wpf}$ & $8 \mathrm{wpf}$ & $10 \mathrm{wpf}$ & $12 \mathrm{wpf}$ & $\begin{array}{c}14 \\
\mathrm{wpf}\end{array}$ \\
\hline Boron_(0 g/ha) & $\begin{array}{l}0.950 \pm \\
0.450 \mathrm{a}\end{array}$ & $\begin{array}{l}1.775 \pm \\
0.025 \mathrm{a}\end{array}$ & $\begin{array}{l}1.250 \pm \\
0.250 \mathrm{a}\end{array}$ & $\begin{array}{l}1.700 \pm \\
0.300 \mathrm{a}\end{array}$ & $\begin{array}{l}1.300 \pm \\
0.300 \mathrm{a}\end{array}$ & $\begin{array}{l}1.800 \pm \\
0.200 \mathrm{a}\end{array}$ & $\begin{array}{c}0.700 \\
\pm \\
0.300 \\
\mathrm{a}\end{array}$ \\
\hline $\begin{array}{c}\text { Boron_(31.25 } \\
\mathrm{g} / \mathrm{ha})\end{array}$ & $\begin{array}{l}1.167 \pm \\
0.167 \mathrm{a}\end{array}$ & $\begin{array}{l}2.383 \pm \\
0.217 \mathrm{a}\end{array}$ & $\begin{array}{l}2.133 \pm \\
0.467 \mathrm{a}\end{array}$ & $\begin{array}{l}1.700 \pm \\
0.300 \mathrm{a}\end{array}$ & $\begin{array}{c}2.283 \pm \\
0.883 \\
\mathrm{ab}\end{array}$ & $\begin{array}{l}2.167 \pm \\
1.167 \mathrm{a}\end{array}$ & $\begin{array}{c}1.200 \\
\pm \\
0.800 \\
\mathrm{a}\end{array}$ \\
\hline $\begin{array}{c}\text { Boron_(41.67 } \\
\mathrm{g} / \mathrm{ha})\end{array}$ & $\begin{array}{l}2.625 \pm \\
0.125 \mathrm{a}\end{array}$ & $\begin{array}{l}7.000 \pm \\
2.500 \mathrm{~b}\end{array}$ & $\begin{array}{l}6.875 \pm \\
1.625 \mathrm{~b}\end{array}$ & $\begin{array}{l}6.625 \pm \\
1.375 \mathrm{~b}\end{array}$ & $\begin{array}{c}3.875 \pm \\
1.125 \\
\mathrm{ab}\end{array}$ & $\begin{array}{l}3.125 \pm \\
0.375 \mathrm{a}\end{array}$ & $\begin{array}{c}2.125 \\
\pm \\
0.625 \\
\mathrm{a}\end{array}$ \\
\hline $\begin{array}{c}\text { Boron_(83.27 } \\
\text { g/ha) }\end{array}$ & $\begin{array}{l}3.125 \pm \\
2.625 \mathrm{a}\end{array}$ & $\begin{array}{l}7.125 \pm \\
2.625 \mathrm{~b}\end{array}$ & $\begin{array}{l}7.125 \pm \\
0.625 \mathrm{~b}\end{array}$ & $\begin{array}{l}6.375 \pm \\
0.625 \mathrm{~b}\end{array}$ & $\begin{array}{c}5.250 \pm \\
1.250 \\
\mathrm{ab}\end{array}$ & $\begin{array}{l}3.000 \pm \\
0.500 \mathrm{a}\end{array}$ & $\begin{array}{c}0.500 \\
\pm \\
0.000 \\
\mathrm{a}\end{array}$ \\
\hline $\operatorname{Pr}>\mathrm{F}$ & 0.679 & 0.023 & 0.008 & 0.007 & 0.105 & 0.503 & 0.374 \\
\hline $\begin{array}{l}\text { Significant } \\
\text { effect }\end{array}$ & No & Yes & Yes & Yes & No & No & No \\
\hline
\end{tabular}

The means of 4 replicates \pm SE followed by the same letter are not significantly different. Data were box-cox transformed before computing ANOVA. wpf: Week post flowering's peak onset. 
Boron applied early in December did not improve significantly the number of cherelles formed on CSSVD-stressed cacao trees compared to the control (all p-values > 0.05) (data not shown).

\section{Boron induces a high number of normally shaped pods on the CSSV- diseased cacao trees.}

Regardless of the application period, higher doses of boron (including the recommended dose) did improve the number of pods exhibiting a normal shape. The recommended dose of boron $(41.67 \mathrm{~g} / \mathrm{ha})$ induced a gain of 4 pods significantly compared to the control (figure11).

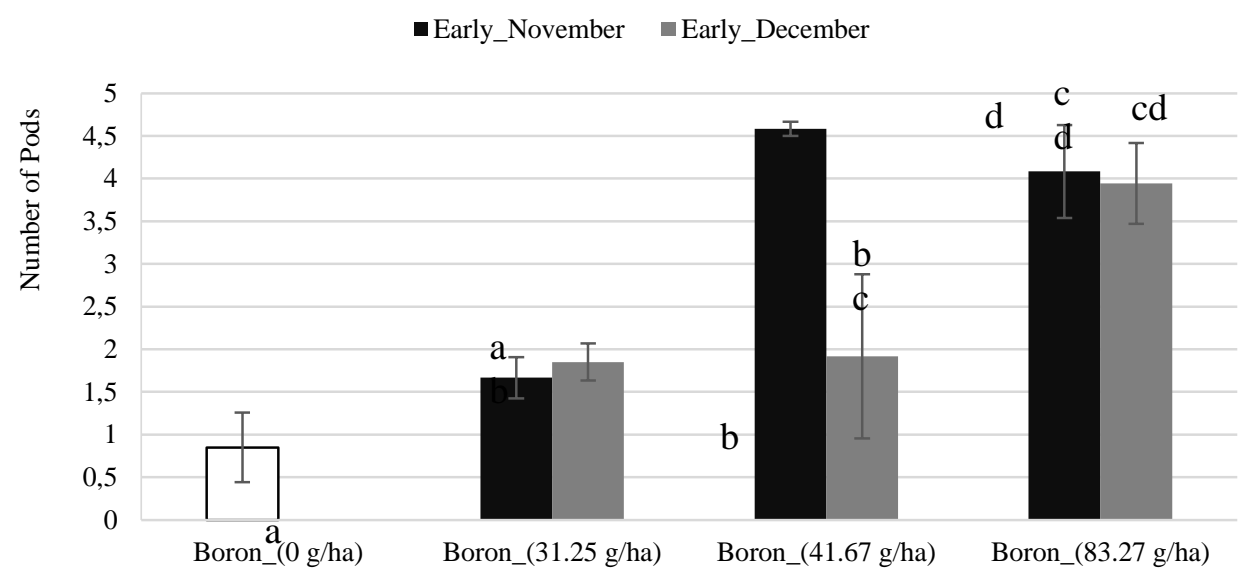

Figure 11: Number of pods per tree obtained by the different doses of boron.

The bars which are means of 4 replicates \pm SE followed by the same letter are not significantly different. Data were box-cox transformed before computing ANOVA.

\section{Boron improves total fresh weight and size of cocoa beans produced on CSSV-diseased trees}

Cocoa beans' fresh weight was increased when boron was applied, but surprisingly, the lowest dose $(31.25 \mathrm{~g} / \mathrm{ha})$ gave the highest weight regardless of the period of application (Figure 12). 


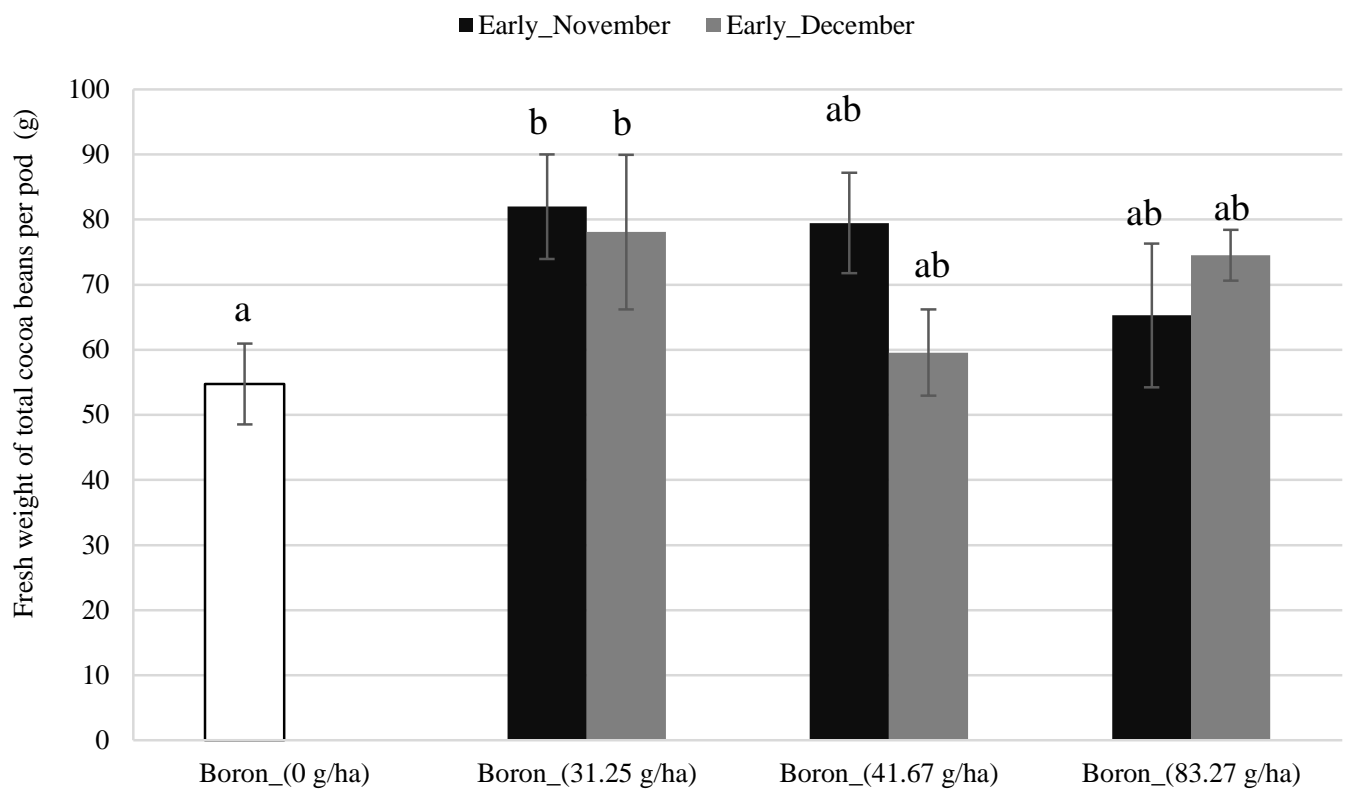

Figure 12: Fresh weight of cocoa beans per pod obtained by the different doses of boron.

The bars which are means of 4 replicates \pm SE followed by the same letter are not significantly different.

On cocoa beans' length data, there was a significant interaction between dose and period of application. Treatments early in November at dose $31.25 \mathrm{~g} /$ ha or at the beginning of December at the highest dose gave the longest cocoa beans (Table 4).

Table 4: Comparison of average length of cocoa beans from different boron treatments

Period

Early in November

Early in November

Early in December

Early in December

Early in December

Early in November

Early in December

Early in November
Dose of boron

$83.27 \mathrm{~g} / \mathrm{ha}$

$0 \mathrm{~g} / \mathrm{ha}$

$0 \mathrm{~g} / \mathrm{ha}$

$41.67 \mathrm{~g} / \mathrm{ha}$

$31.25 \mathrm{~g} / \mathrm{ha}$

$41.67 \mathrm{~g} / \mathrm{ha}$

$83.27 \mathrm{~g} / \mathrm{ha}$

$31.25 \mathrm{~g} / \mathrm{ha}$
Means of cocoa beans' length

$18,265 \pm 0,929 \mathrm{c}$

$18,794 \pm 1,444 \mathrm{c}$

$18,794 \pm 1,444 \mathrm{c}$

$19,524 \pm 0,240 \mathrm{bc}$

$20,387 \pm 0,425 \mathrm{bc}$

$21,247 \pm 1,465 \mathrm{abc}$

$22,163 \pm 0,287 \mathrm{ab}$

$23,447 \pm 0,043 \mathrm{a}$

The means of 4 replicates \pm SE followed by the same letter are not significantly different.

However, the thinnest cocoa beans were recorded when $83.27 \mathrm{~g}$ of boron per ha was applied early in November (Table 5).

Table 5: Comparison of the average width of cocoa beans obtained from the different treatments

\begin{tabular}{ccc}
\hline Period & Dose of boron & Average width of cocoa beans \\
\hline Early in November & $83.27 \mathrm{~g} / \mathrm{ha}$ & $09,461 \pm 1,950 \mathrm{c}$ \\
Early in December & $83.27 \mathrm{~g} / \mathrm{ha}$ & $10,127 \pm 1,318 \mathrm{~b}$ \\
\hline
\end{tabular}




\begin{tabular}{lcc}
\hline Early in December & $31.25 \mathrm{~g} / \mathrm{ha}$ & $10,600 \pm 1,089 \mathrm{ab}$ \\
Early in November & $41.67 \mathrm{~g} / \mathrm{ha}$ & $10,998 \pm 1,310 \mathrm{ab}$ \\
Early in November & $0 \mathrm{~g} / \mathrm{ha}$ & $11,747 \pm 1,107 \mathrm{ab}$ \\
Early in December & $0 \mathrm{~g} / \mathrm{ha}$ & $11,747 \pm 1,107 \mathrm{ab}$ \\
Early in December & $41.67 \mathrm{~g} / \mathrm{ha}$ & $12,001 \pm 0,940 \mathrm{a}$ \\
Early in November & $31.25 \mathrm{~g} / \mathrm{ha}$ & $12,149 \pm 1,864 \mathrm{a}$ \\
\hline
\end{tabular}

The means of 4 replicates \pm SE followed by the same letter are not significantly different.

\section{Application's period differently impacts the number of CSSV-induced flat cocoa beans}

A significant decrease in the number of flat cocoa beans was only recorded when boron was applied at the onset of the flowering peak suggesting an effect of the application period on this relevant parameter of the impact of disease on yield. (Figure 13).

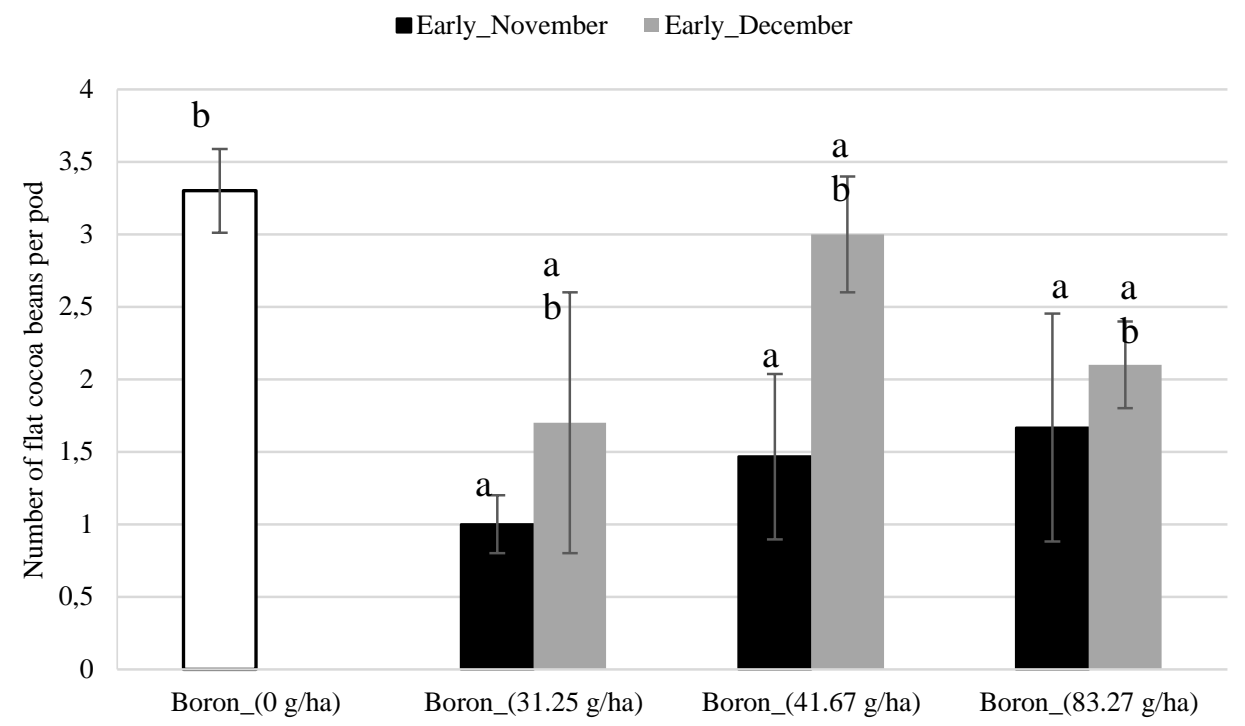

Figure 13: Histogram of the number of flat cocoa beans per pod

\section{Principal Component Analysis (PCA) of the measured parameters}

The quantitative parameters were subjected to a principal component analysis. It resulted that the bigger the cocoa beans are, the more they are prone to be flat under CSSV stress (Table 6).

Table 6: Matrix of correlations between the parameters

\begin{tabular}{|c|c|c|c|c|c|c|c|c|c|}
\hline & $\begin{array}{l}\text { Number } \\
\text { of pods }\end{array}$ & $\begin{array}{l}\text { Mass } \\
\text { of } \\
\text { full } \\
\text { pod }\end{array}$ & $\begin{array}{l}\text { Fresh } \\
\text { weight } \\
\text { of } \\
\text { cocoa } \\
\text { beans }\end{array}$ & $\begin{array}{c}\text { Number } \\
\text { of } \\
\text { cocoa } \\
\text { beans }\end{array}$ & $\begin{array}{c}\text { Number } \\
\text { of flat } \\
\text { cocoa } \\
\text { beans }\end{array}$ & $\begin{array}{c}\text { Coefficient } \\
\text { of } \\
\text { evolution } \\
\text { of } \\
\text { flowering }\end{array}$ & $\begin{array}{l}\text { Number } \\
\text { of } \\
\text { cherelles }\end{array}$ & $\begin{array}{l}\text { Length } \\
\text { of } \\
\text { cocoa } \\
\text { beans }\end{array}$ & $\begin{array}{l}\text { Width } \\
\text { of } \\
\text { cocoa } \\
\text { beans }\end{array}$ \\
\hline
\end{tabular}




\begin{tabular}{|c|c|c|c|c|c|c|c|c|c|}
\hline & & & \multicolumn{7}{|c|}{ intensity } \\
\hline $\begin{array}{l}\text { Number } \\
\text { of pod }\end{array}$ & 1.00 & .51 & .45 & .18 & -.42 & .51 & .92 & .09 & -.05 \\
\hline $\begin{array}{l}\text { Mass of } \\
\text { full pod }\end{array}$ & .51 & 1.00 & .78 & -.25 & -.15 & .04 & .29 & .79 & .62 \\
\hline $\begin{array}{l}\text { Fresh } \\
\text { weight } \\
\text { of cocoa } \\
\text { beans }\end{array}$ & .45 & .78 & 1.00 & -.43 & .19 & -.01 & .32 & .80 & .76 \\
\hline $\begin{array}{l}\text { Number } \\
\text { of cocoa } \\
\text { beans }\end{array}$ & .18 & -.25 & -.43 & 1.00 & -.32 & .31 & .42 & -.75 & -.67 \\
\hline $\begin{array}{c}\text { Number } \\
\text { of flat } \\
\text { cocoa } \\
\text { beans }\end{array}$ & -.42 & -.15 & .19 & -.32 & 1.00 & -.27 & -.49 & .27 & .62 \\
\hline $\begin{array}{c}\text { Number } \\
\text { of } \\
\text { flower }\end{array}$ & .51 & .04 & -.01 & .31 & -.27 & 1.00 & .46 & -.22 & -.35 \\
\hline $\begin{array}{l}\text { Number } \\
\text { of } \\
\text { cherelles }\end{array}$ & .92 & .29 & .32 & .42 & -.49 & .46 & 1.00 & -.18 & -.28 \\
\hline $\begin{array}{l}\text { Length } \\
\text { of cocoa } \\
\text { beans }\end{array}$ & .09 & .79 & .80 & -.75 & .27 & -.22 & -.18 & 1.00 & .91 \\
\hline $\begin{array}{l}\text { Width } \\
\text { of cocoa } \\
\text { beans }\end{array}$ & -.05 & .62 & .76 & -.67 & .62 & -.35 & -.28 & .91 & 1.00 \\
\hline
\end{tabular}

The correlation coefficients significantly different from zero at the 5\% level are in bold.

Overall, the statistical and data analyses revealed that the best treatments are 41.67 or $83.27 \mathrm{~g} / \mathrm{ha}$ of boron applied early in November for the little milking. Indeed, the resulting number of pods was significantly the highest, the length of cocoa beans was closely the highest, and the width was the lowest; which could have favored a reduced number of flat cocoa beans given the positive correlation between cocoa beans width and flat cocoa beans number. Although $83.27 \mathrm{~g} / \mathrm{ha}$ applied early in December greatly increased the number of pods and fresh weight of cocoa beans, the cocoa beans were the most filiform. 


\section{Discussions}

The edaphoclimatic conditions during the study allowed to observe symptoms of CSSVD on leaves, shoots, and pods. These observations were also made by Kouakou et al. (2011) in the rural zone of Bazré located in central-west Cote d'Ivoire. The similarity between the symptoms of our experimental site and Bazré led to suspect the occurrence of CSSV group B strains. Moreover, according to the description of symptoms that are typical of the nature of the strain (Kouakou et al. 2012), strains of group C and intermediate group B-C might have been present in the experimental field. The fact that swollen shoot symptom was not observed markedly might indicate the absence of the group D (Kouakou et al., 2012). However, detection of viral strains by symptomatology is not a very reliable technique. It would be more interesting to use a molecular tool such as IC-PCR with specific antibodies and primers (Kouakou et al., 2012).

Application of boron at $41.67 \mathrm{~g} / \mathrm{ha}(203.28 \mathrm{~g}$ of the commercial product per ha) and $83.27 \mathrm{~g} / \mathrm{ha}$ doses $(406.18 \mathrm{~g}$ of the commercial product per ha) increased the foliar density. This result could be due to the stimulation of meristematic processes of leaf formation (Loué, 1993).

Although only $83.27 \mathrm{~g} / \mathrm{ha}$ dose guaranteed less deformed pods regardless of the period of application, this effect could be a consequence of boron impact on the rigidity of the cell walls (Loué, 1993). This result was consistent with conclusions from Spann et al. (2010). The authors pointed out that viral infection symptoms sometimes disappeared when the mineral element was widely available, even if the whole plant was infected. Indeed, visible symptoms depended on competition between the virus and host cells for nutrients (Spann et al., 2010).

Flowering intensity diagrams for sprays at the beginning of flowering peak (early in November), showed that boron led to an increased production of flowers compared to the control. The induced growth was positively correlated with increasing boron dosage. This finding was consistent with those of O'niell et al. (2004). However, this outcome may depend on the periods of application. Indeed, the treatments applied four weeks later did not increase the emission of flowers. These findings corroborate the observations made by Olaiya et al. (2006) who concluded that boron sprays at the onset of the flowering were more efficient on flowering intensities than the postponed ones. The effect of the highest dose contrasted with those of Olaiya et al. (2006). Nevertheless, this result suggests that boron did not lose its ability to stimulate flowering despite the presence of the CSSV.

The analysis of the variance on the number of cherelles and the number of pods showed that only an effect of factor 'dose' and especially that of dose $83.27 \mathrm{~g} /$ ha promoted the highest number of cherelles and pods. This outcome was likely a consequence of the impact onto the flowering 
intensities. The cacao trees seemed to be sufficiently boron-fertilized to increase the number of flowers, pollen fertility, pollination rate, and to enhance its capacity to evade CSSV-induced wilt of cherelles in situ on the tree. According to Boyer (1974), the wilting of cherelles is a physiological phenomenon which can be due to a lack of carbohydrate and other photosynthesis products resulting from CSSV attack. Boron could, therefore, contribute to the upkeep of the photosynthesis process and improve the carbohydrates translocation (Dugger and Humphreys, 1960). All of these findings, therefore, point up that the swollen shoot virus does not revoke the effects of boron. Boron has favored an increase in pod' yield in cacao trees stressed by the cocoa swollen shoot disease.

The number of cocoa beans per pod remained the same for all treatments. This outcome was identical for the parameter "fresh weight of the full pod" which are relevant indicators of the disease, signifying that boron did not have any real impact on these CSSVD symptoms. However, boron did reduce the CSSVD-induced flat cocoa beans' number when, interestingly, it was applied at early peak flowering with the lowest dose (31.25 g/ha).

The interaction between dose and application period had a significant effect $(\mathrm{p}<0.05)$ on the length and width of cocoa beans. The best results were obtained by the highest dose applied early in November and December respectively. However, the correlation between the parameters presented by the PCA showed that the number of CSSVD-induced flat cocoa beans was positively correlated with the width of the cocoa beans. These results pointed up that the width decreased with increasing doses. Therefore, higher doses of boron could indirectly reduce the CSSV activity that flattens cocoa beans.

Boron applied at $31,25 \mathrm{~g} / \mathrm{ha}$ significantly improved the total fresh weight of the cocoa beans regardless of the period of application. The dose $83.27 \mathrm{~g} / \mathrm{ha}$ and $41.67 \mathrm{~g} / \mathrm{ha}$ had an intermediate effect between that of control and $31.25 \mathrm{~g} / \mathrm{ha}$. This parameter is an indicator of both yield and the disease. However, the finding suggested a negative correlation between the fresh weight of cocoa beans and boron' dosages. Indeed, it seemed from our study that increasing dose of boron would favor pods' and cocoa beans number instead of their fresh weight. This impression was confirmed by the correlation between the parameters given by the PCA. Spann et al. (2010) stated that although the symptoms of viral infections sometimes disappeared when the mineral element was widely available, competition between the virus and the plant for nutrients varied depending on the diseases and could be influenced by environmental factors, such as temperature. Their point of view might explain the increase in a particular symptom such as decreasing weight of cocoa beans despite the availability of nutrients like boron in the plant. 
Overall, treatments early in November at $41.67 \mathrm{~g}$ of boron per ha gave the best-expected results. The trial' results have shown that boron enhanced cacao trees' tolerance to the CSSVD. However, the boron effect on the viral load needed to be assessed, as it was the case with Tobacco mosaic virus on beans and tobacco, Tomato yellow leaf curl virus and Tomato mosaic virus on tomatoes (Dordas, 2008; Eraslan et al., 2007; Shepherd et al., 1960).

\section{Conclusion}

The study is to our knowledge the first report of Boron-induced tolerance of cacao trees to the CSSVD. This key finding is noteworthy for the management of the disease by agricultural practices such as mineral fertilization plannings, notably in old plantations made of susceptible clones facing virulent CSSV strains. This study deserves further investigations, particularly a precise identification of the strains of the virus present and an analysis of the viral load after the application of boron. Besides, it would be advisable to study the effect of a combination of boron with zinc, silicon, and calcium which also confer resistance to plant viral diseases.

\section{Acknowledgment}

The authors are grateful to Mr. David Mallard from the Louis Dreyfus Commodities - Cote d'Ivoire company for the financial and material support. The authors are also thankful to Pr. Thérèse Atcham Agneroh and Mr. Joël Dingui for their contribution during seminars.

\section{References:}

1. Altieri, M. A., \& Nicholls, C. I. (2003). Soil fertility management and insect pests: harmonizing soil and plant health in agroecosystems. Soil and Tillage Research,72(2), 203-211. doi:10.1016/s0167-1987(03)00089-8.

2. Ameyaw, G. A., Domfeh, O., Dzahini-Obiatey, H., Ollennu, L. A. A., \& Owusu, G. K. (2016). Appraisal of Cocoa swollen shoot virus (CSSV) Mild Isolates for Cross Protection of Cocoa Against Severe Strains in Ghana. Plant Disease, 100(4), 810-815.

3. Ameyaw, G. A., Dzahini-Obiatey, H. K., \& Domfeh, O. (2014). Perspectives on cocoa swollen shoot virus disease (CSSVD) management in Ghana. Crop Protection, 65, 64-70.

4. Ameyaw, G. A., Wetten, A., Dzahini-Obiatey, H., Domfeh, O., \& Allainguillaume, J. (2012). Investigation on Cacao swollen shoot virus(CSSV) pollen transmission through cross-pollination. Plant Pathology, 62(2), 421-427. doi:10.1111/j.1365-3059.2012.02640.x 
5. Bhat, A. I., Hohn, T., \& Selvarajan, R. (2016). Badnaviruses: the current global scenario. Viruses, 8(6), 177.

6. Boyer, J. (1974). Étude écophysiologique du développement de cacaoyers cultives au Cameroun. II. Influence des facteurs climatiques prépondérants fur la floraison et la fructification. Café Cacao Thé.

7. Calvet, G. \& Villemin, P. (1986). Interprétation des analyses de terre. SCPA. France. 24p.

8. Dongo, L. N., \& Orisajo, S. B. (2007). Status of cocoa swollen shoot virus disease in Nigeria. African Journal of Biotechnology, 6(17).

9. Dordas, C. (2009). Role of nutrients in controlling plant diseases in sustainable agriculture: a review. In Sustainable Agriculture (pp. 443460). Springer Netherlands.

10. Dugger Jr, W. M., \& Humphreys, T. E. (1960). Influence of boron on enzymatic reactions associated with biosynthesis of sucrose. Plant Physiology, 35(4), 523.

11. Dzahini-Obiatey, H., Domfeh, O., \& Amoah, F. M. (2010). Over seventy years of a viral disease of cocoa in Ghana: from researchers perspective. African Journal of Agricultural Research, 5(7), 476-485.

12. Eraslan, F., Akbas, B., Inal, A., \& Tarakcioglu, C. (2007). Effects of foliar sprayed calcium sources on Tomato mosaic virus (ToMV) infection in tomato plants grown in greenhouses. Phytoparasitica, 35(2), 150-158.

13. F.A.O. (2003). Les engrais et leurs applications, Précis à l'usage des agents de vulgarisation agricole., Quatrième édition, Editions F.A.O., I.F.A. (Paris, France) et IMPHOS (Casablanca, Maroc). $84 \mathrm{P}$.

14. Gao, X., Wu, M., Xu, R., Wang, X., Pan, R., Kim, H. J., \& Liao, H. (2014). Root interactions in a maize/soybean intercropping system control soybean soil-borne disease, red crown rot. PLoS One, 9(5), e95031.

15. Kébé, BI, N'Guessan, KF, Tahi, GM, Assiri, AA, Koko, LK, Kohi, NJ, Irié, BZ et Koffi, N. (2009). Bien cultiver le cacaoyer en Côte d'Ivoire. Fiche Technique. Centre National de Recherche Agronomique (CNRA) - CTA, DPRAD \& DISI, $4 \mathrm{p}$.

16. Koko, L. K., Kassin, K. E., Assiri, A. A., Yoro, G., N'goran, K., \& Snoeck, D. (2011). Fertilisation minérale du cacaoyer (Theobroma cacao L.) en Côte d'Ivoire: Acquis vulgarisables et perspectives de recherche. Agronomie Africaine, 23(3), 217-225.

17. Koko, L. K., Snoeck, D., Lekadou, T. T., \& Assiri, A. A. (2013). Cacao-fruit tree intercropping effects on cocoa yield, plant vigour and light interception in Côte d'Ivoire. Agroforestry Systems, 87(5), 1043-1052. https://doi.org/10.1007/s10457-013-9619-8 
18. Kouakou, K., Kébé, B. I., Kouassi, N., Aké, S., Cilas, C., \& Muller, E. (2012). Geographical distribution of Cacao swollen shoot virus Molecular Variability in Côte d'Ivoire. Plant disease, 96(10), 14451450.

19. Kouakou, K., Kébé, B. I., Kouassi, N., Anno, A. P., Aké, S., \&Muller, E. (2011). Impact de la maladie virale du swollen shoot du cacaoyer sur la production de cacao en milieu paysan à Bazré (Côte d'Ivoire). Journal of Applied Biosciences, 43, 2947-2957.

20. Krauss, U., \& Soberanis, W. (2002). Effect of fertilization and biocontrol application frequency on cocoa pod diseases. Biological control, 24(1), 82-89.

21. Lachenaud, P., \& Mossu, G. (1985). Étude comparative de l'influence de deux modes de conduite sur les facteurs du rendement d'une cacaoyère (Côte d'Ivoire). Café, Cacao, Thé, 29(1), 21-30.

22. Lockhard, B.E.L., Sackey, S.T. (2001). Cacao swollen shoot. In: Encyclopedia of plant pathology. O.C. Maloy et T.D. Murray, eds. John Wiley \& Sons, Inc., New York, pp: 172-173.

23. Lockhart, B. E. L. (1990). Evidence for a double-stranded circular DNA genome in a second group of plant viruses. Phytopathology, 80(2), 127-131.

24. Loué, A. (1993). Oligo-éléments en agriculture. Ed. SCPA. 577 p.

25. Mossu, G., Paulin, D., \& De Reffye, P. (1981). Influence de la floraison et de la pollinisation sur les rendements du cacaoyer. Liaisons mathématiques entre les données expérimentales. Équation du rendement. Café, Cacao, the, 25(3), 155-168.

26. Olaiya A.O. \& Fagbayide J.A., 2006. Effets des pulvérisations de Bore, d'Acide Naphtalène acétique et d'acide gibbérellique sur le développement des cabosses et le rendement. $15^{\text {ème }}$ conférence internationale sur la recherche cacaoyère, $7^{\text {ème }}$ session, Juin 2006, San José, Costa Rica.

27. Ollennu, L. A. A., \& Owusu, G. K. (2002). Spread of cocoa swollen shoot virus to cacao (Theobroma cacao L.) plantings in Ghana. Tropical agriculture, 79(4), 224-230.

28. Ouattara, Z.L. (2008). Analyse technique et socio-économique de l'exploitation agropastorale de Bohitiefla-Bouafla (Bouaflé). Rapport de stage de fin de première année agronomique. ESA/INP-HB Yamoussoukro, Côte d'Ivoire. p 15

29. Partiot, M. (1983). Le swollen shoot du cacaoyer (\#Theobroma cacao\#, Sterculiacées): étude de la nature et de l'évolution d'un couple hôte-parasite dans un écosystème tropical.

30. Ploetz, R. C. (2007). Cacao diseases: important threats to chocolate production worldwide. Phytopathology, 97(12), 1634-1639. 
31. Shepherd, R. J., \& Pound, G. S. (1960). Influence of boron nutrition of Nicotiana tabacum on the multiplication of tobacco mosaic virus. Phytopathology, 50, 26-30.

32. Spann, T. M., \& Schumann, A. W. (2010). Mineral nutrition contributes to plant disease and pest resistance. University of Florida, IFAS Extension HS1181.

33. Steven, W. F. (1936). A new disease of cocoa in the Gold Coast. Tropical Agriculture, Trinidad, 14.

34. Vos, G. M., Ritchie, B. J., \& Flood, J. (2003). À la découverte du cacao: un guide pour la formation des facilitateurs. CABI Bioscience. 